\title{
Considerations regarding the security influences of the covid- 19 pandemic on the public health field in Romania
}

\author{
Cătălin Peptan ${ }^{1}$; Silvana-Elena Peptan ${ }^{2}$ \\ ${ }^{1}$ Constantin Brancusi University of Targu Jiu, Romania \\ ${ }^{2}$ Societe Generale Global Solution Centre SA, Romania \\ E-mail: catalinpeptantm@gmail.com
}

\begin{abstract}
Starting from the importance of the public health field in Romania's national security gear, the authors analyze the impact of the SARS-CoV-2 coronavirus on this field, highlighting some of the security consequences of the COVID-19 pandemic generated by the new coronavirus. The proposed analysis covers the period 28.02.2020-15.09.2021 and highlights the evolution of some statistical parameters representative for the description of the COVID-19 pandemic, such as: the number of cases of people infected with coronavirus (total cases, active cases, cured cases, deaths); testing dynamics and vaccination dynamics, including the adverse reactions that occurred during the vaccination process, in the context of the high degree of transmissibility and contagion of the coronavirus.

The study highlights that Romania is on one of the last places in the European Union (EU) in terms of vaccination rate of the population, despite a campaign heavily publicized and supported by the authorities, determined by the spread in the public space of conspiracy theories regarding the origins of coronavirus and the side effects of vaccination on the population, in the context of the emergence of adverse reactions to the administration of certain types of vaccine. It is highlighted that the delay in obtaining mass immunization of the population has detrimental consequences on the health and for the evolution of social life in the next period.
\end{abstract}

Keywords: health, SARS-CoV-2 coronavirus, COVID-19 pandemic, security, testing, vaccination.

\section{National evolution of the COVID-19 pandemic}

The issue of the COVID-19 pandemic has been intensely debated nationally and internationally in recent years, both by opinion leaders and by specialists in medical sciences or security studies. There are a multitude of studies [17] that try to elucidate the causes of the occurrence, the ways of manifestation, the social and security consequences and, last but not least, the measures to be taken to combat the effects of the pandemic.

It is well known that the health of the population is a fundamental indicator that reflects the level of socio-economic and cultural development of a state. In this context, the national health system has an exceptional role in the gear of national security of Romania, a role currently highlighted by the National Strategy for National Defense for the period 2021-2024 [16], which provides as priority directions of action in this field: increasing the capacity of manifestation of the public health system in case of pandemics or emergencies; remodeling the health system in the sense of positioning the patient at the top of the pyramid of its concerns; aligning policies on labor market developments in line with the specificities of the fields of education and health; resolving problematic issues related to the demographic situation and mitigating inequalities regarding the level of regional development. 
The importance of health at a national level is also highlighted by the fact that in the Romanian Constitution [22], art. 34, is recorded „The right to health care”, by which the state is obliged to ensure public health and the right to health for its citizens. Also, Romania has the Law no. 95/2006, republished, regarding the health care reform, which stipulates the organizational and action framework in order to protect and promote the health of the population. It is also worth noting that, after 1989, the fields of education and health were declared as priority areas, at national level, by the decision-making authorities in the state.

The report on Romania's health profile for 2019 showed that our country has serious problems in managing most of the public health sector and has an outdated structure of the medical system as a whole, with a very high rate of hospitalizations, which generates very high costs for hospital units, requiring a strict restructuring of health services at the national level. Also, life expectancy in Romania is among the lowest in the EU, behavioral risk factors are quite widespread, representing a major threat to public health (diet is poor, alcohol consumption is high, lack of physical activity). The report also concludes that the level of health spending is the lowest in the EU, both per capita and as a percentage of GDP, the underfunding of the system affecting our country's ability to manage the needs of citizens in optimal conditions. These realities are more than worrying if we take into account the fact that the shortage of health professionals is very high, their number being among the lowest in EU countries. The report also highlights the fact that our health system is facing „governance problems”, lacking transparency and a coherent mechanism for assessing performance in the field. [21] It should also be mentioned that Romania is based on a model of social health insurance that gives the state a major role, and the small number of contributors to social health insurance means that the national health system is underfunded.

The beginning of 2020 coincided with the emergence of exceptional challenges for the public health system, both nationally and globally, with almost immeasurable consequences so far, caused by the new coronavirus SARS-CoV-2, whose tentacles have spread rapidly worldwide. The medical world witnessed almost helplessly, in the first half of 2020, the perverse manifestations of the new coronavirus, given its unique characteristics. [11, 19] The major risk of exposure of people and the very diversified symptomatology, was likely to make it difficult for them to realize in the early stages a more accurate diagnosis of the symptoms. However, the exceptional efforts of the medical world, carried out all over the world, have made it possible, since the second half of last year, to decipher the mechanisms of evolution of the virus and to identify means of counteracting it.

The analysis of official data on the evolution of the spread of SARS-CoV-2 coronavirus at the national level [5, 24], from the date of the first case (28.02.2020) until the end of the analyzed period (15.09.2021), highlights the very high degree of contagion, statistical parameters in absolute figures and percentage assessments (for the case of deceased persons) being given in Tab. 1.

Table 1. The evolution of the spread of SARS-CoV-2 coronavirus at the national level

\begin{tabular}{|c|c|c|c|c|c|c|c|}
\hline Cases/Date & $\begin{array}{c}\text { Total } \\
\text { cases }\end{array}$ & $\begin{array}{c}\text { Healed } \\
\text { cases }\end{array}$ & $\begin{array}{c}\text { Active } \\
\text { cases }\end{array}$ & Hospitalizations & $\begin{array}{c}\text { ICU } \\
\text { hospitalizati } \\
\text { ons }\end{array}$ & $\begin{array}{c}\text { Deaths } \\
(\text { abs. } \\
\text { value })\end{array}$ & $\begin{array}{c}\text { Deaths } \\
(\%)\end{array}$ \\
\hline 01.03 .2020 & 3 & 3 & 0 & 0 & 0 & 0 & 0 \\
\hline 01.04 .2020 & 2460 & 257 & 2070 & 483 & 78 & 138 & 5,60 \\
\hline 01.05 .2020 & 12567 & 4567 & 7353 & 1420 & 249 & 786 & 6,25 \\
\hline 01.06 .2020 & 18938 & 13426 & 4673 & 1221 & 159 & 1289 & 6,8 \\
\hline 01.07 .2020 & 27296 & 19384 & 4880 & 1318 & 222 & 1667 & 4,27 \\
\hline 01.08 .2020 & 52111 & 27364 & 17790 & 7445 & 401 & 2379 & 4,56 \\
\hline 01.09 .2020 & 88593 & 38454 & 35283 & 7164 & 522 & 3681 & 4,15 \\
\hline 01.10 .2020 & 129658 & 105994 & 20802 & 7617 & 557 & 4862 & 3,74 \\
\hline 01.11 .2020 & 246663 & 157975 & 63621 & 11498 & 910 & 7067 & 2,86 \\
\hline
\end{tabular}


Volume 3, Issue 2, 2021

ISSN: 2668-0416

Thoth Publishing House

\begin{tabular}{|c|c|c|c|c|c|c|c|}
\hline Cases/Date & $\begin{array}{c}\text { Total } \\
\text { cases }\end{array}$ & $\begin{array}{c}\text { Healed } \\
\text { cases }\end{array}$ & $\begin{array}{c}\text { Active } \\
\text { cases }\end{array}$ & Hospitalizations & $\begin{array}{c}\text { ICU } \\
\text { hospitalizati } \\
\text { ons }\end{array}$ & $\begin{array}{c}\text { Deaths } \\
\text { (abs. } \\
\text { value) }\end{array}$ & $\begin{array}{c}\text { Deaths } \\
(\%)\end{array}$ \\
\hline 01.12 .2020 & 479634 & 360936 & 107710 & 13438 & 1259 & 11530 & 2,40 \\
\hline 01.01 .2021 & 636141 & 566365 & 53935 & 8734 & 1117 & 15841 & 2,49 \\
\hline 01.02 .2021 & 729990 & 675767 & 35821 & 7895 & 971 & 18402 & 2,52 \\
\hline 01.03 .2021 & 804036 & 741471 & 42162 & 8334 & 1022 & 20403 & 2,56 \\
\hline 01.04 .2021 & 959918 & 856405 & 78839 & 13252 & 1434 & 23674 & 2,46 \\
\hline 01.05 .2021 & 1056338 & 992605 & 35589 & 8087 & 1277 & 28194 & 2,66 \\
\hline 01.06 .2021 & 1077978 & 1040527 & 7098 & 2159 & 410 & 30353 & 2,80 \\
\hline 01.07 .2021 & 1080106 & 1045351 & 895 & 430 & 21 & 33861 & $3.1 \%$ \\
\hline 01.08 .2021 & 1081283 & 1047677 & 770 & 411 & 59 & 34286 & $3.17 \%$ \\
\hline 01.09 .2021 & 1100208 & 1055892 & 9725 & 2455 & 293 & 34591 & $3,14 \%$ \\
\hline 15.09 .2021 & 1130586 & 1070645 & 24726 & 5868 & 696 & 35215 & $3,11 \%$ \\
\hline
\end{tabular}

The statistical processing of the collected data highlights the graphical variation of the COVID19 evolution for the analyzed time interval, presented in Figure 1.

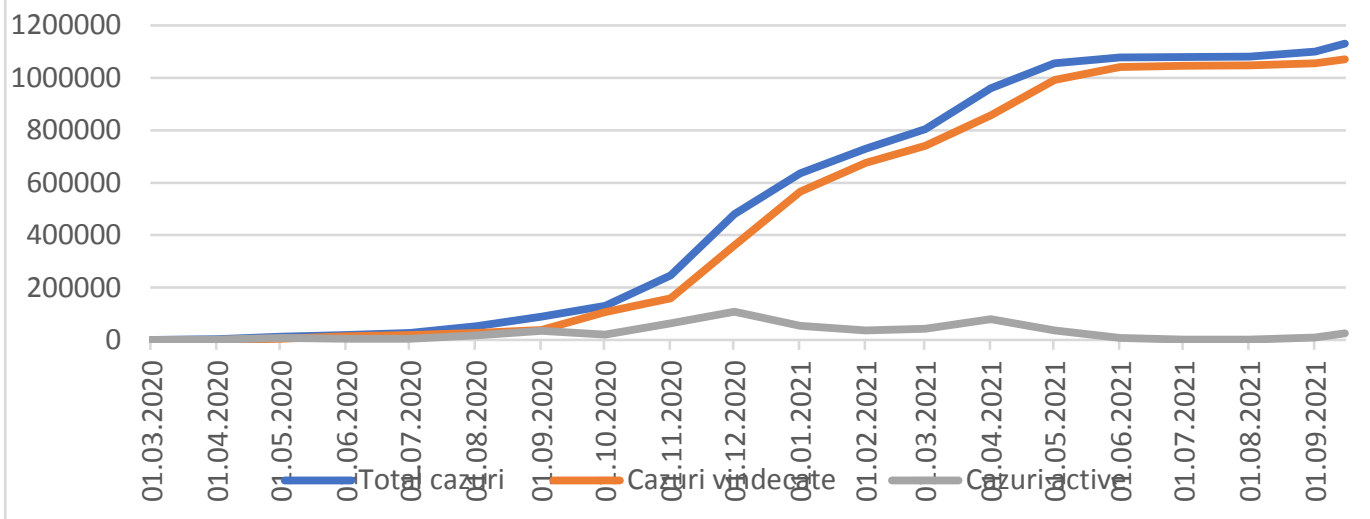

Figure 1 Graphic variation of the general evolution at national level

The following conclusions of interest can be drawn:

- Despite the efforts of health care workers and the authorities involved, the number of people infected with the SARS-CoV-2 coronavirus has been steadily increasing until early May 2021, a temporary milestone that foreshadows a predictable horizon for a significant reduction in the effects of coronavirus.

- In the analyzed interval, the evolution of the pandemic experienced four „waves”, which were characterized by rapid evolutions of the characteristics highlighted in Tab.1, respectively: the first wave, between the date of the beginning of the pandemic and the end of May 2020 (by GD No. 434/28.05. 2020 relaxation measures are introduced); the second wave, between mid-October and the end of December 2020, the third wave, between the second half of March 2021 and the beginning of May 2021, and the fourth wave, foreshadowed by the second decade of July 2021, which was characterized by a progressive increase in the number of infected people, experts saying that its aggression has manifested itself since September 2021.

- April, 2021, was characterized by a significant decrease in the number of active cases, the number of hospitalizations in ICU wards (after April 11), as well as the number of deaths, which foreshadowed, at that time, optimistic prospects for managing the evolution of the pandemic and subsequently substantiated the adoption of relaxation measures by the authorities responsible for managing the issue. 
- The third wave, which appeared in the context of the circulation of new strains of coronavirus and the predisposition of the population not to comply with the rules imposed by the authorities to prevent coronavirus infection, was characterized by severe forms of respiratory failure, usually doubled by liver failure, which pose special problems in treating patients.

- The fourth wave of the pandemic is characterized by the high number of infections with the Delta strain of coronavirus (characterized by a high degree of transmissibility and contagiousness), mainly affecting unvaccinated people, a special feature being the fact that the incidence of the virus is also found in young people and children.

Regarding the evolution of active cases, from Figure 2 it can be concluded that the evolution of the pandemic determined the appearance of serious forms that required the increase of the number of patients hospitalized in the ICU between November-December 2020, as an effect of the second wave of the pandemic, as well as starting with March 2021, with the onset of the third wave of the pandemic. Also, a problematic situation is registered starting with September 2021, amid the alarming increase in the number of hospitalizations in ICU wards.

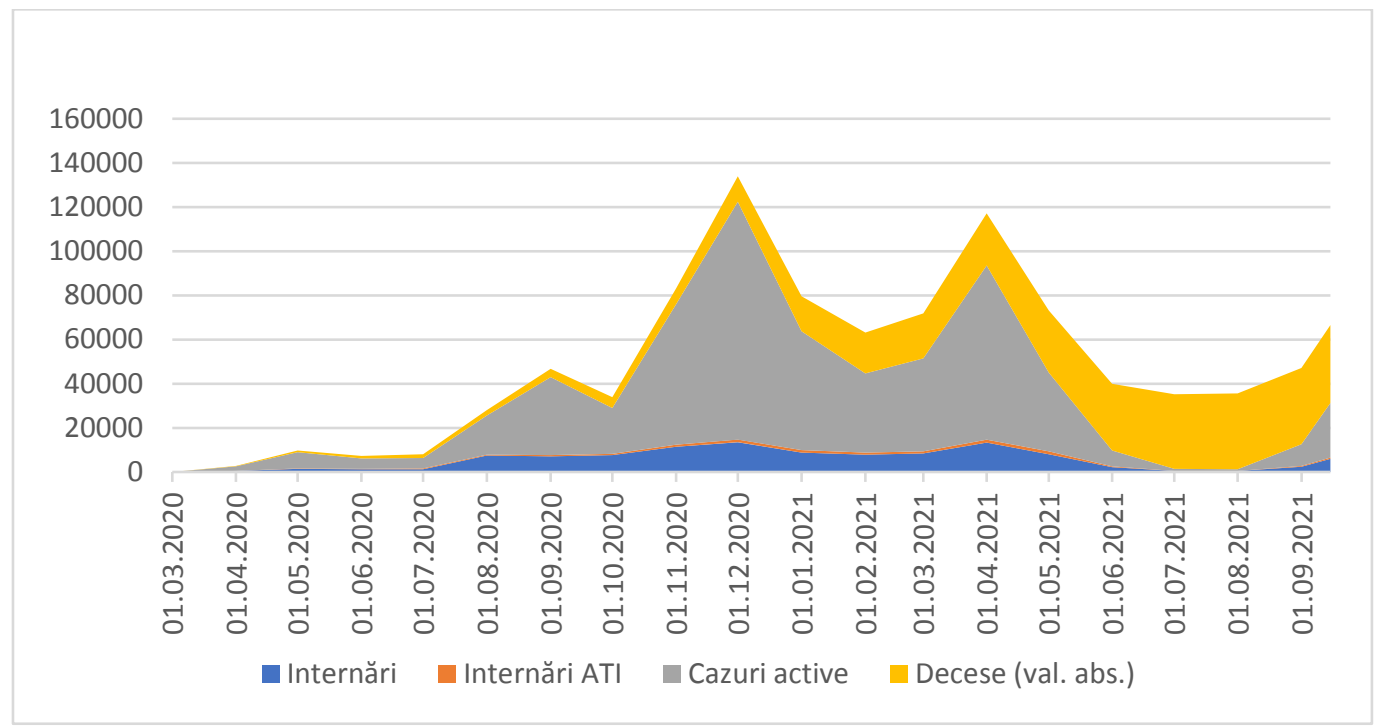

Figure 2 Graphic variation of the evolution of active cases and hospitalizations at national level

It is also worth mentioning that the death rate was high in the first months after the appearance of the coronavirus. Calculated as a ratio between the number of deaths and the total number of confirmed persons, at the end of the analyzed period it was around 3,15\%.

The evolution of the COVID-19 pandemic at national level, during its entire duration of manifestation, was characterized by „very high and unpredictable potential for aggression (...)” [10], which raised special challenges for medical specialists.

The COVID-19 pandemic determined the state authorities and the employees of the Romanian medical system to prioritize their efforts for the priority treatment of patients infected with the new coronavirus, some wards or hospital units specialized in treating patients with other diseases being temporarily closed or significantly reducing their capacity. In this context, opinion formers or specialists from the medical world appeared in the public space, claiming that patients suffering from other diseases, who could not benefit from qualified medical services except, possibly, in an emergency, had their constitutional right to health care violated.

In order to be able to express some personal opinions on this subject, a comparative analysis $[12,13]$ of the main indicators that highlight the health status of the population for the years 2020 and 2019 is presented in Tab. 2. 
Table 2 A comparative analysis of the health status of the population for the years 2020 and 2019

\begin{tabular}{|l|r|r|c|}
\hline \multicolumn{1}{|c|}{ Medical cases } & \multicolumn{1}{c|}{$\begin{array}{l}\text { Year } \\
\mathbf{2 0 1 9}\end{array}$} & Year 2020 & $\begin{array}{l}\text { Reporting } \\
\mathbf{2 0 2 0 / 2 0 1 9}\end{array}$ \\
\hline Number of pregnancies recorded & 109210 & 98038 & 0,90 \\
\hline Incidence of tuberculosis & 11117 & 7221 & 0,65 \\
\hline Evidence of cancer patients & 59606 & 49593 & 0,83 \\
\hline Evidence of diabetes & 76967 & 59919 & 0,78 \\
\hline Evidence of mental illness & 46745 & 32563 & 0,70 \\
\hline Evidence of children with protein-caloric malnutrition & 1608 & 1683 & 1,05 \\
\hline Rickets & 7721 & 7715 & 0,99 \\
\hline Obesity & 343982 & 333321 & 0,97 \\
\hline Mental illness & 230998 & 230858 & 0,99 \\
\hline Alzheimer's disease & 34543 & 34844 & 1,01 \\
\hline Mental disorders & 502140 & 510797 & 1,02 \\
\hline Epilepsy & 124433 & 119717 & 0,96 \\
\hline Rheumatic heart diseases & 41136 & 40114 & 0,97 \\
\hline Hypertensive disease & 2640031 & 2560370 & 0.97 \\
\hline Ischemic heart disease & 1208096 & 1171600 & 0.97 \\
\hline Famous-vascular diseases & 376922 & 373930 & 0,99 \\
\hline Cirrhosis & 310517 & 308801 & 0,99 \\
\hline Ulcerative disease & 281971 & 266866 & 0,95 \\
\hline Down disease & 4157 & 4069 & 0,98 \\
\hline
\end{tabular}

It can be noted that the qualitative indicators, in absolute numbers, for 2020 are lower than in the previous year, in most cases of medical diagnoses analyzed, which could lead, at first sight, to the conclusion that the health of the population as a whole has improved. Such a conclusion is superficial and even false, especially if we consider that the pandemic caused by the coronavirus SARS-CoV-2 has negative effects, direct or secondary, on other diseases that people may face. However, the hypothesis exposed in the public space must be accepted, according to which the persons registered with other medical diagnoses besides COVID-19 could not benefit, at least in the first part of 2020, when the pandemic was registered in Romania, from optimal treatment conditions in state medical units in our country.

This state of affairs generated a very virulent public rhetoric, which brought to attention the crisis of the Romanian health system. It is worth mentioning, in context, the point of view expressed by prof. $\mathrm{PhD}$. Dan Poenaru, according to which: „The current „crisis of the health system” is partially artificial, the health field being an emotional and very tempting subject for the media and the political struggle. To get out of the so-called crisis, in general, ,specialists" refer to financing, construction, purchase of equipment and others. It is true that these are also important, but I want to draw other aspects that I consider vital: the loss of the relationship of trust between doctor and patient is a very serious thing that is happening now and from which patients will suffer; the evaluation of the medical specialists should be made on criteria in which the professional arguments should be preponderant. Let's re-evaluate meritocracy; depoliticization of the health management act; separation of the private medical system from the public one; hospital autonomy; intensification of health education and prophylaxis activities; state encouragement of birth rates, Romania currently having major demographic problems" ( Interview given to the author, on 15.05.2021). 


\section{Considerations on how to combat the COVID-19 pandemic. Testing and Vaccination, Pros \& Cons}

At the international level, it is estimated that one of the measures that must be adopted in the fight against the COVID-19 pandemic is the massive testing of the population. Successful campaigns in Austria or Slovakia, to identify infected people, isolate them and treat them properly, have been able to raise awareness among the Romanian authorities with competences in the field to implement a population testing program at national level, in the context of the alarming growth of the number of infections. Moreover, the need to provide a clear picture of the epidemiological status, in order to adopt the necessary measures, can be achieved through a coherent population testing program, in accordance with the recommendations of the World Health Organization. It is also worth mentioning, in context, the European Commission's recommendation of 18 December 2020 on the implementation of a common framework for the use and mutual recognition at EU level of rapid antigen tests for the detection of people infected with the SARS-CoV-2 coronavirus.

The Commissioner for Health and Food Safety of the European Commission, Ms Stella Kyriakides, referring to the role of antigenic tests in managing the complex issue caused globally by the new pandemic, especially in terms of its spread, said: „Fast antigens give us the speed, reliability and ability to respond quickly to isolating COVID cases. This is essential to slow the spread of the pandemic. [7] Similar points of view were expressed by Romanian specialists, prof. PhD. Carmen Mihaela Dorobăț, claiming that „Testing is absolutely essential to have a correct and true picture of what is happening in society at a given time". [3]

During the analyzed period, a bimonthly evaluation of the total number of tests [6], respectively of the positive ones, is presented in the following table (Tab. 3).

Table 3 A bimonthly evaluation of the total number of tests

\begin{tabular}{|l|l|l|l|l|l|l|l|l|}
\hline Date & 01.03 .20 & 15.03 .20 & 01.04 .20 & 15.04 .20 & 01.05 .20 & 15.05 .20 & 01.06 .20 & 15.06 .20 \\
\hline Total & 0 & 276 & 1955 & 4730 & 8314 & 8384 & 4055 & 3682 \\
\hline Positive & 0 & 16 & 215 & 337 & 327 & 190 & 141 & 166 \\
\hline Date & 01.07 .20 & 15.07 .20 & 01.08 .20 & 15.08 .20 & 01.09 .20 & 15.09 .20 & 01.10 .20 & 15.10 .20 \\
\hline Total & 12585 & 18440 & 23451 & 23986 & 22326 & 21049 & 25797 & 29857 \\
\hline Positive & 326 & 641 & 1225 & 1398 & 1053 & 1111 & 2086 & 4013 \\
\hline Date & 01.11 .20 & 15.11 .20 & 01.12 .20 & 15.12 .20 & 01.01 .21 & 15.01 .21 & 01.02 .21 & 15.02 .21 \\
\hline Total & 21556 & 23166 & 14625 & 25185 & 15957 & 31079 & 8995 & 9775 \\
\hline Positive & 5324 & 7094 & 4272 & 6171 & 3938 & 3353 & 1313 & 1331 \\
\hline Date & 01.03 .21 & 15.03 .21 & 01.04 .21 & 15.04 .21 & 01.05 .21 & 15.05 .21 & 01.06 .21 & 15.06 .21 \\
\hline Total & 11593 & 12217 & 41985 & 37517 & 16438 & 32709 & 26785 & 29633 \\
\hline Positive & 2096 & 2972 & 6156 & 3852 & 1307 & 729 & 241 & 103 \\
\hline Date & 01.07 .21 & 15.07 .21 & 01.08 .21 & 15.08 .2021 & 01.09 .2021 & 15.09 .2021 & & \\
\cline { 1 - 5 } Total & 25984 & 24920 & 21899 & 27134 & 42847 & 44608 & &
\end{tabular}

Statistical analysis of data on population testing highlights a non-uniform approach to the issue by the responsible authorities, with major fluctuations in the number of tests performed, maximum for 2020 remaining around 30,000 tests/ ay in the second half of it, although the maximum testing capacity at national level was 55,000 tests/day.

It is noted the increase of the testing capacity of the population starting with the second decade of March 2021, as a complementary measure to the national vaccination program, likely to contribute to the efficiency of the fight against coronavirus. It is also worth noting the position of the Minister of Health, who appreciated, in May 2021, that „Testing has an essential role in limiting the spread of the SARS-CoV-2 virus. The correct use of rapid tests, in large numbers and ensuring a short time between application and access to testing (...) has a significant role in reducing the spread of the virus." [18] Moreover, this increase can be considered as the result of the very acid public rhetoric of the opinion vectors in the Romanian society, regarding the reluctance/disinterest of the Romanian medical 
authorities to massively test the population, considering that the relief of a high degree of infestation population as a result of the tests would be likely to lead to the implementation of administrative measures, such as the quarantine of certain urban or rural settlements.

The emergence of the fourth wave of the pandemic has brought to the attention of the competent national authorities and opinion leaders the need for mass testing of the population, including as an express requirement for citizens to participate in certain societal events. The graphical variation of the evolution of the number of people tested/identified as positive is presented in Figure 3, noting on the whole a relationship of direct proportionality between the number of tests and the number of persons identified as positive.

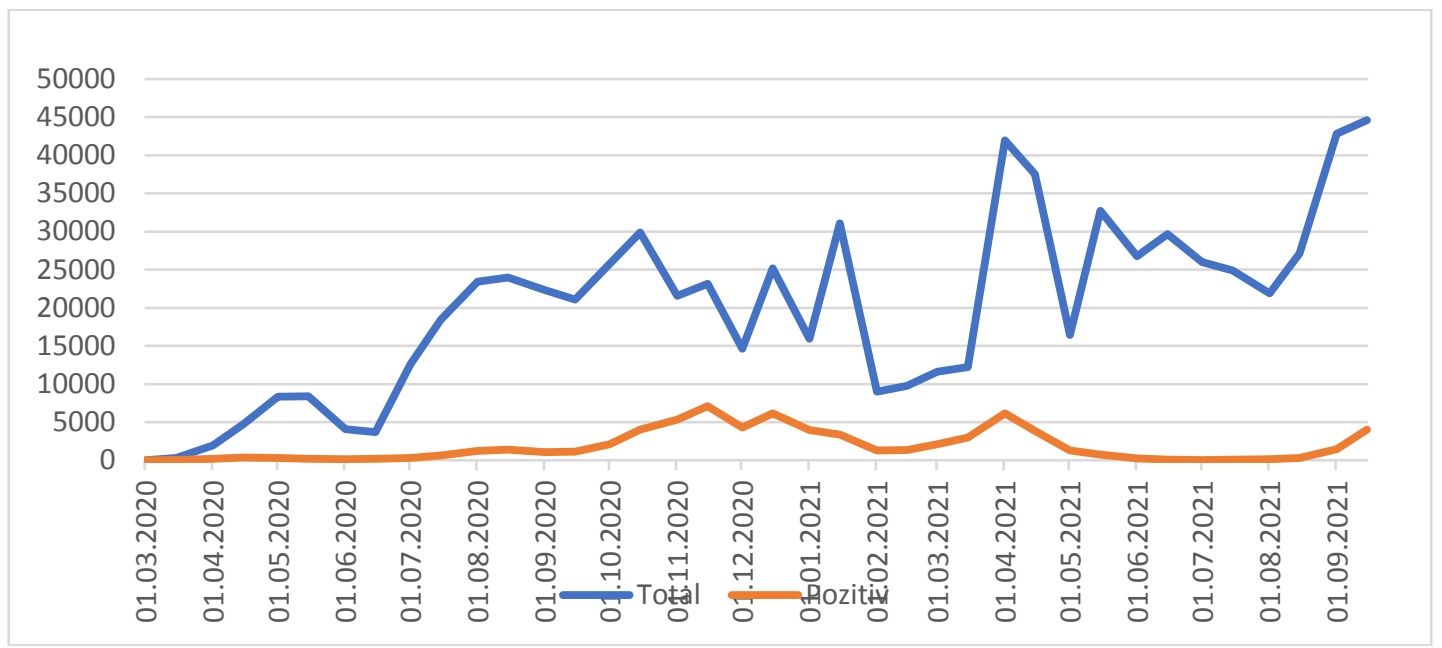

Figure 3 Graphic variation of antiCOVID-19 tests

Even before the emergence of the SARS-COV-2 virus, one of the important indicators of the use of health services in the country was the vaccination coverage of the main preventable diseases by vaccination, which has decreased substantially in recent years, both in hepatitis and and measles or the flu.

In September 2019, just a few months before the onset of the COVID-19 pandemic, the European Commission and the World Health Organization (WHO) held the first World Summit on Vaccination in Brussels, calling it ,a global challenge that we must address together now”, as stated by the President of the European Commission, Jean-Claude Juncker, and the Director-General of WHO, Dr Tedros Adhanom Ghebreyesu, with the aim of accelerating global action to combat the spread of preventable diseases through immunization. The two senior officials considered that ,it is inadmissible that, in a world as developed as ours, there are still children dying of diseases that should have been eradicated long ago in Europe; worse than that, we have the necessary solution, but it is not used at full capacity; by vaccination, 2-3 million deaths a year are already prevented and another 1.5 million could be prevented if the global coverage of vaccination were improved; (...) after many years of progress, we are at a critical moment, measles is coming back strong, while 1 in 10 children are not yet taking advantage of the essential childhood vaccines "[23].

The key to achieving this goal is for national and international authorities and citizens to view immunization as a universal human right, as a social good and as an indispensable element in ensuring the health of the individual. In fact, two years ago, the WHO considered that the reluctance of the population to respond to vaccination campaigns could be perceived as a global security and health threat, with group immunization being considered the most effective way to respond to the incidence of virus spread. At European level, following the proposal of the European Commission, the EU Council forwarded in December 2018 Recommendation (2018/C466/01) [8] on strengthening cooperation in the 
fight against vaccine-preventable diseases, recommending the conceptualization and operationalization of vaccination plans at European level, in order to achieve the objectives of the WHO European Vaccination Action Plan by 2020.

The pandemic caused by the SARS-CoV-2 coronavirus posed exceptional challenges to the medical world, channeling all efforts (increased research capabilities in the context of existing technologies, public and/or private funding, prioritization of evaluation by licensing bodies), to identify vaccine that confers immunity to persons. [15] Experts believe that vaccination is the only safe and effective measure that can protect the population, this being scientifically and practically proven in the case of other types of poliovirus. Prof. PhD. Alexandru Rafila is optimistic about the discovery of vaccines to limit the circulation of the new coronavirus, issuing some opinions on the need to prioritize/rank the categories of people to be vaccinated. [26]

The efforts of the specialists were crowned by the identification in a record time of the COVID-19 vaccines, as is the case of the Pfizer BioNTech, Moderna, Astra Zeneca or Johnson \& Johnson vaccines, which ensure a high level of efficacy (approximately 95\% in the case of Pfizer BioNTech and Moderna vaccines, approximately $72 \%$ for the Astra Zeneca vaccine and $67 \%$ for the Johnson \& Johnson vaccine).[9] In these circumstances, the production of COVID-19 vaccines was likely to allow the start, at the end of 2020, of a large-scale global vaccination campaign in Romania starting on December 26, 2020 , ensuring the access of all persons to the vaccination action, effectively, avoiding the overcrowding of vaccination centers or the loss of vaccine doses.

Public rhetoric has been diverse and controversial about the level of immunization conferred by vaccination, or about its possible side effects, but beyond the pros and cons, vaccination is considered by both specialists in the field and most opinion formers, the only effective way to re-enter humanity in the state of normalcy, even if other strategies for pandemic management have been brought to the attention. [2] I note that some similar points of view have been expressed, since the end of 2019, by prof. $\mathrm{PhD}$. Adrian Strainu Cercel, who publicly supported the need to vaccinate the population, arguing that the fight against the virus will be won when , $80 \%$ of the population will be vaccinated”. [25] Assoc. Prof. PhD. Voichița Lăzureanu, claims that ,vaccination is extremely necessary and the only way to prevent viral and bacterial infections”, being „our only weapon against this virus”. [4]

The analysis of official data [20] on vaccination to ensure the immunization of the Romanian population against the SARS-CoV-2 coronavirus highlights the concern of state authorities for streamlining the program, the statistical parameters recorded since its inception (27.12.2020) and until now (15.09.2021) being reproduced in Table 4.

Table 4 The official data on vaccination

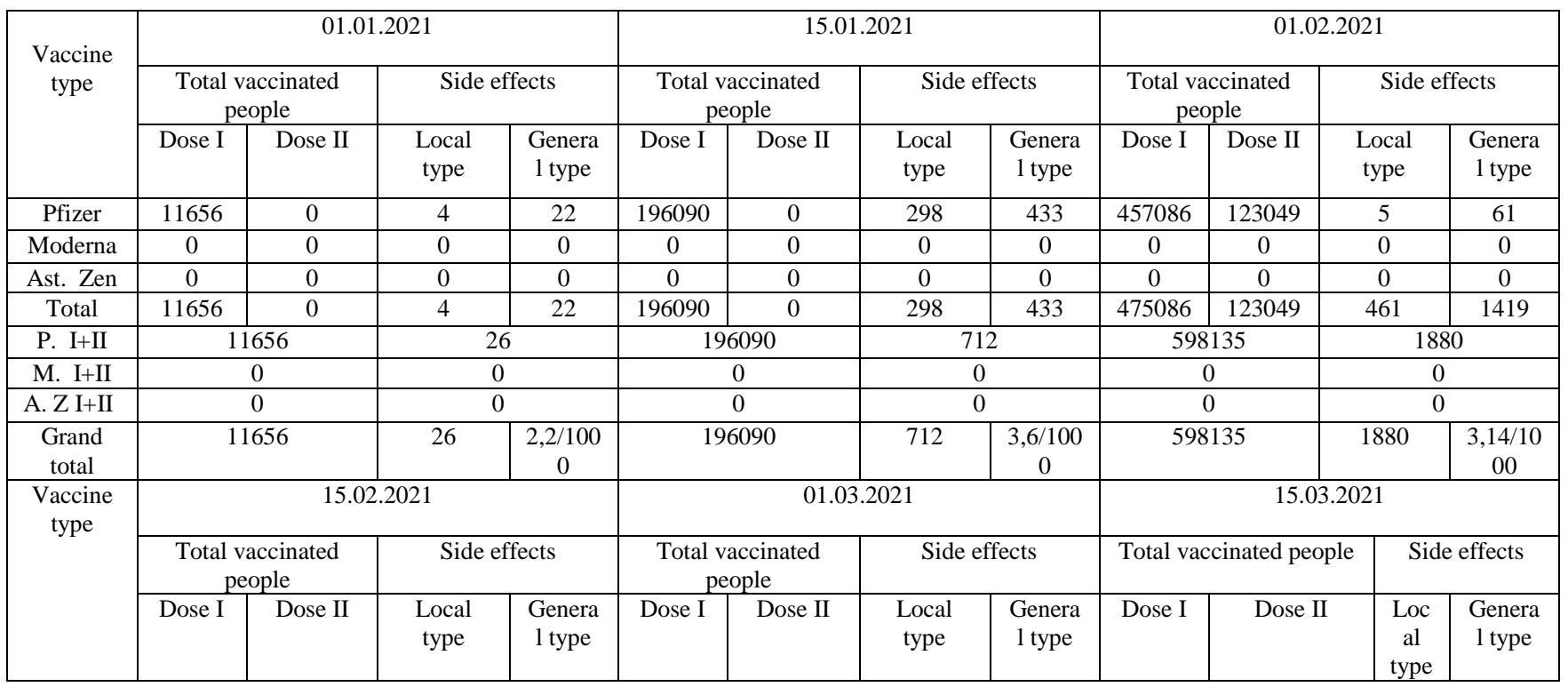


Volume 3, Issue 2, 2021

ISSN: 2668-0416

Thoth Publishing House

\begin{tabular}{|c|c|c|c|c|c|c|c|c|c|c|c|c|}
\hline Pfizer & 175047 & 454168 & 556 & 2324 & 110860 & 618240 & 628 & 3004 & 503157 & 602810 & 698 & 3377 \\
\hline Moderna & 60915 & 1 & 9 & 75 & 77811 & 1 & 54 & 233 & 22108 & 60147 & 63 & 351 \\
\hline Ast Zen. & 6812 & 0 & 4 & 3 & 139869 & 0 & 27 & 1512 & 238961 & 0 & 44 & 2791 \\
\hline Total & 242774 & 454169 & 569 & 2402 & 328540 & 618241 & 709 & 4249 & 764226 & 722957 & 805 & 6519 \\
\hline P I+II & \multicolumn{2}{|c|}{1083383} & \multicolumn{2}{|c|}{2880} & \multicolumn{2}{|c|}{1347340} & \multicolumn{2}{|c|}{3632} & \multicolumn{2}{|c|}{1828777} & \multicolumn{2}{|c|}{4075} \\
\hline M I+II & \multicolumn{2}{|c|}{60917} & \multicolumn{2}{|c|}{84} & \multicolumn{2}{|c|}{77812} & \multicolumn{2}{|c|}{287} & \multicolumn{2}{|c|}{142402} & \multicolumn{2}{|c|}{414} \\
\hline A.Z I+II & \multicolumn{2}{|c|}{6812} & \multicolumn{2}{|c|}{7} & \multicolumn{2}{|c|}{139868} & \multicolumn{2}{|c|}{1539} & \multicolumn{2}{|c|}{238961} & \multicolumn{2}{|c|}{2835} \\
\hline $\begin{array}{l}\text { Grand } \\
\text { total }\end{array}$ & \multicolumn{2}{|c|}{1151112} & 2971 & $\begin{array}{c}4,2 / 100 \\
0\end{array}$ & \multicolumn{2}{|c|}{1565021} & 5458 & $\begin{array}{c}3,5 / 100 \\
0 .\end{array}$ & \multicolumn{2}{|c|}{2210140} & \begin{tabular}{c|c}
737 \\
4
\end{tabular} & $\begin{array}{c}3,3 / 100 \\
0 \\
\end{array}$ \\
\hline Vaccine & & 01.0 & & & & 15.04 & & & & 01.05 & 021 & \\
\hline & $\begin{array}{r}\text { Total } \\
\mathrm{p}\end{array}$ & $\begin{array}{l}\text { ccinated } \\
\text { pple }\end{array}$ & Side & ects & $\begin{array}{r}\text { Total v } \\
\text { pe }\end{array}$ & $\begin{array}{l}\text { ccinated } \\
\text { ple }\end{array}$ & Side & fects & $\begin{array}{r}\text { Total } \\
\mathrm{p}\end{array}$ & $\begin{array}{l}\text { ccinated } \\
\text { ple }\end{array}$ & Side & ffects \\
\hline & Dose I & Dose II & $\begin{array}{l}\text { Local } \\
\text { type }\end{array}$ & $\begin{array}{l}\text { Genera } \\
1 \text { type }\end{array}$ & Dose I & Dose II & $\begin{array}{l}\text { Local } \\
\text { type }\end{array}$ & $\begin{array}{l}\text { Genera } \\
1 \text { type }\end{array}$ & Dose I & Dose II & $\begin{array}{l}\text { Local } \\
\text { type }\end{array}$ & $\begin{array}{l}\text { Genera } \\
1 \text { type }\end{array}$ \\
\hline Pfizer & 491896 & 1028416 & 825 & 4232 & 435610 & 1402431 & 970 & 4834 & 968448 & 1638817 & 1136 & 5611 \\
\hline Moderna & 77327 & 76754 & 121 & 709 & 132079 & 93491 & 196 & 910 & 145199 & 160499 & 257 & 1251 \\
\hline Ast Zen. & 365934 & 4 & 98 & 4700 & 376889 & 31279 & 114 & 5568 & 259544 & 164323 & 123 & 5801 \\
\hline Total & 935157 & 1138301 & 1044 & 9641 & 944578 & 1527201 & 1280 & 11312 & $\begin{array}{c}137319 \\
1\end{array}$ & 1963639 & 1516 & 12663 \\
\hline P I+II & & 9130 & & & & 4472 & & & & 5082 & & \\
\hline M I+II & & 835 & & & & 061 & & & & 197 & & \\
\hline AZ I+II & & 942 & & & & 447 & & & & 190 & & \\
\hline $\begin{array}{l}\text { Grand } \\
\text { total }\end{array}$ & & 5907 & 10685 & $\begin{array}{c}3,4 / 100 \\
0\end{array}$ & & 3980 & 12592 & $\begin{array}{l}3,1 / 100 \\
0\end{array}$ & & 4469 & 14179 & $\begin{array}{c}2,7 / 100 \\
0 .\end{array}$ \\
\hline Vaccine & & 15.0 & & & & 01.06 .2021 & & & & 15.06 & 021 & \\
\hline & $\begin{array}{r}\text { Total } \\
\text { p }\end{array}$ & $\begin{array}{l}\text { ccinated } \\
\text { ople }\end{array}$ & Side & ects & $\begin{array}{r}\text { Total } \\
\text { pe }\end{array}$ & $\begin{array}{l}\text { ccinated } \\
\text { ple }\end{array}$ & Side & fects & $\begin{array}{r}\text { Total } \\
\mathrm{p}\end{array}$ & $\begin{array}{l}\text { ccinated } \\
\text { ople }\end{array}$ & Side & ffects \\
\hline & Dose I & Dose II & $\begin{array}{l}\text { Local } \\
\text { type }\end{array}$ & $\begin{array}{l}\text { Genera } \\
1 \text { type }\end{array}$ & Dose I & Dose II & $\begin{array}{l}\text { Local } \\
\text { type }\end{array}$ & $\begin{array}{l}\text { Genera } \\
1 \text { type }\end{array}$ & Dose I & Dose II & $\begin{array}{l}\text { Local } \\
\text { type }\end{array}$ & $\begin{array}{l}\text { Genera } \\
1 \text { type }\end{array}$ \\
\hline Pfizer & 831190 & 2261260 & 1210 & 6196 & 515200 & 2910589 & 1279 & 6680 & 279713 & 3282119 & 1295 & 6645 \\
\hline Moderna & 106914 & 232260 & 268 & 1494 & 49556 & 306086 & 303 & 1646 & 22984 & 338464 & 308 & 1679 \\
\hline Ast Zen. & 170438 & 258649 & 131 & 5904 & 58382 & 372888 & 136 & 5970 & 32685 & 399337 & 108 & 5981 \\
\hline $\mathrm{J} \& \mathrm{~J}$ & & 25538 & 2 & 27 & & 124059 & 11 & 97 & & 225331 & 23 & 170 \\
\hline Total & 134080 & 2752169 & 1627 & 13063 & 747165 & 3589563 & 1718 & 13286 & 747165 & 4245251 & 1649 & 14675 \\
\hline P I+II & & 3710 & & & & 5378 & & & & 3951 & & \\
\hline $\mathrm{M} \mathrm{I}+\mathrm{II}$ & & 436 & & & & 728 & & & & & & \\
\hline AZ I+II & & 736 & & & & 158 & & & & 359 & & \\
\hline $\begin{array}{l}\text { J\&J } \\
\text { I+II }\end{array}$ & & 538 & & & & 072 & & & & & & \\
\hline $\begin{array}{l}\text { Grand } \\
\text { total }\end{array}$ & & 8418 & 14832 & $\begin{array}{c}2,4 / 100 \\
0\end{array}$ & & 5291 & 16102 & $\begin{array}{l}2,03 / 10 \\
00\end{array}$ & & 9553 & 16439 & $\begin{array}{c}1,91 / 10 \\
00\end{array}$ \\
\hline Vaccine & & 01.0 & & & & 15.07 .2021 & & & & 01.08 & 021 & \\
\hline & $\begin{array}{r}\text { Total } \\
\text { p }\end{array}$ & $\begin{array}{l}\text { ccinated } \\
\text { ople }\end{array}$ & Side & ects & $\begin{array}{r}\text { Total } \\
\text { p }\end{array}$ & $\begin{array}{l}\text { ccinated } \\
\text { ople }\end{array}$ & Side & fects & Total & $\begin{array}{l}\text { ccinated } \\
\text { ple }\end{array}$ & Side & ffects \\
\hline & Dose I & Dose II & $\begin{array}{l}\text { Local } \\
\text { type }\end{array}$ & $\begin{array}{l}\text { Genera } \\
1 \text { type }\end{array}$ & Dose I & Dose II & $\begin{array}{l}\text { Local } \\
\text { type }\end{array}$ & $\begin{array}{l}\text { Genera } \\
1 \text { type }\end{array}$ & Dose I & Dose II & $\begin{array}{l}\text { Local } \\
\text { type }\end{array}$ & $\begin{array}{l}\text { Genera } \\
1 \text { type }\end{array}$ \\
\hline Pfizer & 154384 & 3481107 & 1306 & 6923 & $\begin{array}{c}369279 \\
7\end{array}$ & 3559677 & 1317 & 6975 & $\begin{array}{l}375427 \\
5\end{array}$ & 3632966 & 1323 & 7030 \\
\hline Moderna & 12734 & 351478 & 309 & 1691 & 365912 & 356711 & 310 & 1695 & 367830 & 359629 & 310 & 1702 \\
\hline Ast Zen. & 22973 & 409590 & 128 & 5995 & 432593 & 413441 & 138 & 6000 & 432730 & 415388 & 138 & 6005 \\
\hline $\mathrm{J} \& \mathrm{~J}$ & - & 302688 & 26 & 213 & 364623 & 364623 & 28 & 246 & 540601 & 540601 & 29 & 289 \\
\hline Total & 190048 & 4544863 & 1779 & 13251 & $\begin{array}{c}548559 \\
25\end{array}$ & 4694452 & 1793 & 14916 & $\begin{array}{c}500543 \\
6\end{array}$ & 4858584 & 1800 & 15026 \\
\hline Pf. I+II & & 6552 & & & & 474 & & & & 7241 & & \\
\hline Mo. I+II & & 693 & & & & 623 & & & & 459 & & \\
\hline A.Z. I+II & & 153 & & & & 034 & & & & 118 & & \\
\hline $\mathrm{J} \& \mathrm{~J}$ I+II & & 688 & & & & 623 & 27. & & & 601 & & \\
\hline
\end{tabular}


Volume 3, Issue 2, 2021

ISSN: 2668-0416

Thoth Publishing House

\begin{tabular}{|c|c|c|c|c|c|c|c|c|c|c|c|c|}
\hline $\begin{array}{l}\text { Grand } \\
\text { total }\end{array}$ & \multicolumn{2}{|c|}{8977086} & 16601 & $\begin{array}{c}1,85 / 10 \\
00 \\
\end{array}$ & \multicolumn{2}{|c|}{9185754} & 16709 & $\begin{array}{l}1,82 / 10 \\
00\end{array}$ & \multicolumn{2}{|c|}{9413419} & 16826 & $\begin{array}{c}1,79 / 10 \\
00 \\
\end{array}$ \\
\hline \multirow{3}{*}{$\begin{array}{l}\text { Vaccine } \\
\text { type }\end{array}$} & \multicolumn{4}{|c|}{15.08 .2021} & \multicolumn{4}{|c|}{01.09 .2021} & \multicolumn{4}{|c|}{15.09 .2021} \\
\hline & \multicolumn{2}{|c|}{$\begin{array}{c}\text { Total vaccinated } \\
\text { people }\end{array}$} & \multicolumn{2}{|c|}{ Side effects } & \multicolumn{2}{|c|}{$\begin{array}{c}\text { Total vaccinated } \\
\text { people }\end{array}$} & \multicolumn{2}{|c|}{ Side effects } & \multicolumn{2}{|c|}{$\begin{array}{c}\text { Total vaccinated } \\
\text { people }\end{array}$} & \multicolumn{2}{|c|}{ Side effects } \\
\hline & Dose I & Dose II & $\begin{array}{l}\text { Local } \\
\text { type }\end{array}$ & $\begin{array}{l}\text { Genera } \\
1 \text { type }\end{array}$ & Dose I & Dose II & $\begin{array}{l}\text { Local } \\
\text { type }\end{array}$ & $\begin{array}{l}\text { Genera } \\
1 \text { type }\end{array}$ & Dose I & Dose II & $\begin{array}{l}\text { Local } \\
\text { type }\end{array}$ & $\begin{array}{l}\text { Genera } \\
1 \text { type }\end{array}$ \\
\hline Pfizer & $\begin{array}{c}379545 \\
1 \\
\end{array}$ & 3685582 & 1325 & 7065 & $\begin{array}{c}383680 \\
8 \\
\end{array}$ & 3743020 & 1328 & 7103 & $\begin{array}{l}386842 \\
9\end{array}$ & 3775725 & 1334 & 7131 \\
\hline Moderna & 369178 & 381448 & 310 & 1705 & 370472 & 363641 & 310 & 1711 & 371428 & 364899 & 310 & 1714 \\
\hline Ast Zen. & 432745 & 416119 & 138 & 6006 & 432762 & 416845 & 138 & 6010 & 432799 & 417221 & 138 & 6013 \\
\hline $\mathrm{J} \& \mathrm{~J}$ & 528105 & 528105 & 32 & 333 & 618772 & 618772 & 34 & 378 & 670899 & 670899 & 35 & 411 \\
\hline Total & $\begin{array}{c}512547 \\
9\end{array}$ & 4991254 & 1805 & 15109 & $\begin{array}{c}525881 \\
4\end{array}$ & 5142278 & 1810 & 15202 & $\begin{array}{c}534337 \\
5\end{array}$ & 5228744 & 1817 & 15269 \\
\hline Pf. I+II & \multicolumn{2}{|c|}{7481033} & \multicolumn{2}{|c|}{8390} & \multicolumn{2}{|c|}{7579828} & \multicolumn{2}{|c|}{8431} & \multicolumn{2}{|c|}{7644154} & \multicolumn{2}{|c|}{8645} \\
\hline Mo. I+II & \multicolumn{2}{|c|}{730626} & \multicolumn{2}{|c|}{2015} & \multicolumn{2}{|c|}{734113} & \multicolumn{2}{|c|}{2021} & \multicolumn{2}{|c|}{737147} & \multicolumn{2}{|c|}{2024} \\
\hline $\mathrm{J} \& \mathrm{~J} \quad \mathrm{I}+\mathrm{II}$ & \multicolumn{2}{|c|}{528105} & \multicolumn{2}{|c|}{365} & \multicolumn{2}{|c|}{618772} & \multicolumn{2}{|c|}{212} & \multicolumn{2}{|c|}{670899} & & \\
\hline $\begin{array}{l}\text { Grand } \\
\text { total }\end{array}$ & & 628 & 16914 & $\begin{array}{c}1,76 / 10 \\
00\end{array}$ & & 320 & 17012 & $\begin{array}{l}1,74 / 10 \\
00\end{array}$ & & 220 & 17086 & $\begin{array}{c}1,73 / 10 \\
00\end{array}$ \\
\hline
\end{tabular}

Note: The Moderna vaccine has been administered since 4 February 2021, the Astra Zeneca vaccine since 15 February 2021 and the Johnson \& Johnson vaccine since 4 May 2021.

From the beginning of the vaccination period (December 26, 2020) until February 4, 2021, the vaccination was performed exclusively with the Pfizer vaccine.

The variation of the absolute values, at national level, of the number of vaccinated persons (total, dose I and dose II), respectively the evolution of adverse reactions (local type and general type) is presented in Figure 4 - 6.
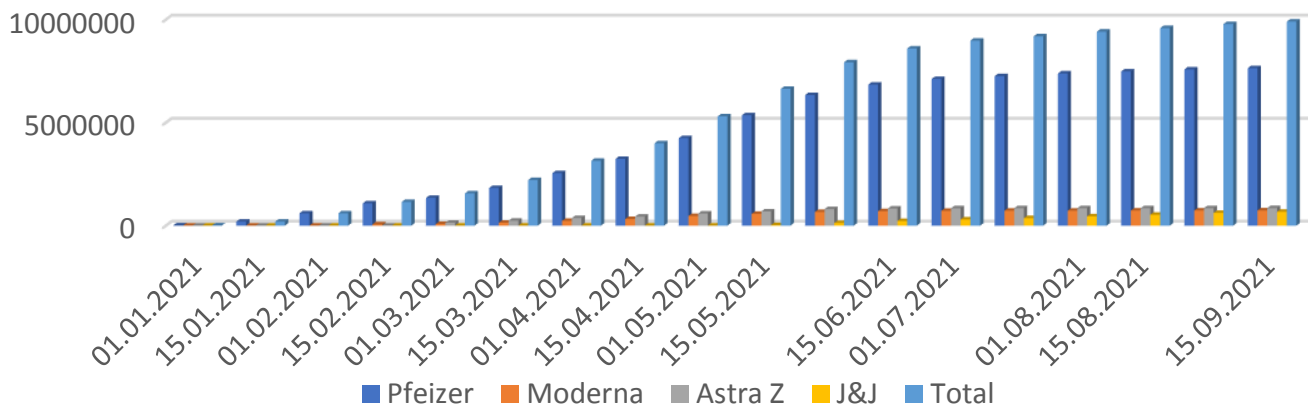

Figure 4 Temporary evolution of the number of vaccine doses administered

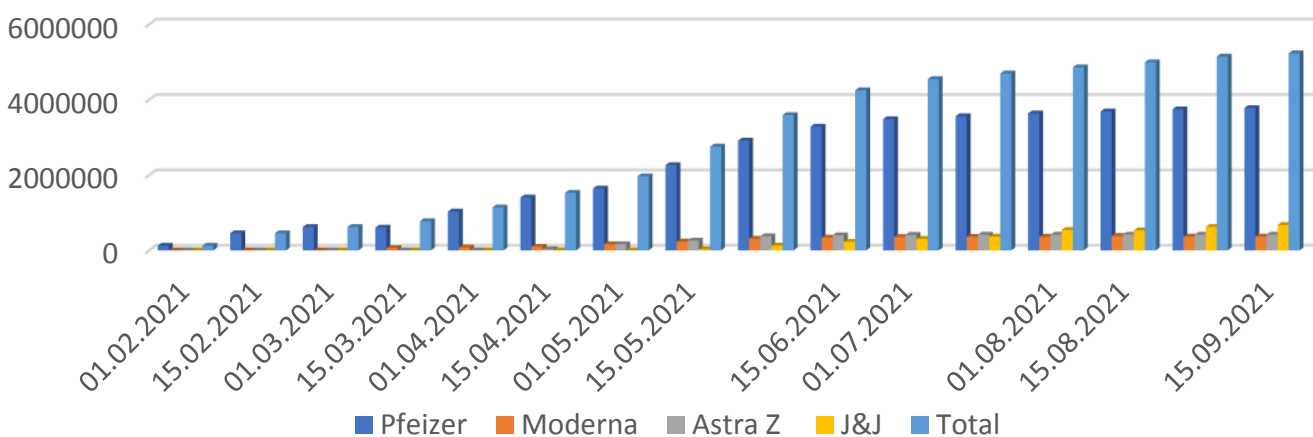


Figure 5 Temporary evolution of full-dose vaccination

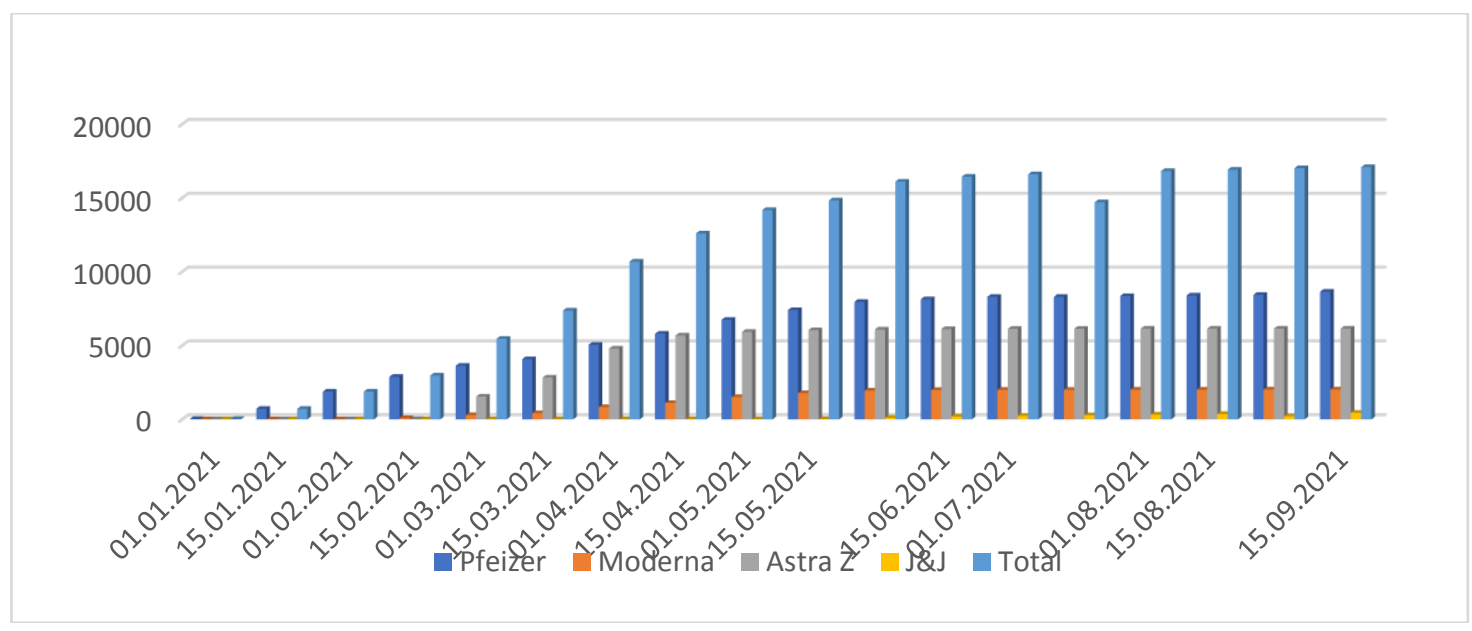

Figure 6 Temporary evolution of adverse reactions

It can be noted that, despite the efforts made by the national authorities in the field, both for the efficiency of the national vaccination program against SARS-CoV-2 coronavirus and for raising public awareness of the need for vaccination, the effects were not as expected, at the end of the analyzed period Romania being among the last countries at EU level in terms of the number of vaccinated persons compared to the total number of inhabitants (about 27\%).

The results of this state of affairs have multiple causality and effects that could prove to be detrimental to the health of the population and to the evolution of social life in the coming period, especially in the context in which since September 2021, at national level there have been multiple cases of infections with new variants of coronavirus that have already manifested in many countries around the world, including European.

One of the causes of the low success rate at national level of the vaccination campaign is determined by the occurrence of adverse reactions whose variation in the analyzed interval is presented in Fig. 6. It is necessary to make some references to the increase in the number of side effects among people who have been given the Astra Zeneca vaccine, which has led to an increase in the population's reluctance to this vaccine, but also to the adoption of certain administrative measures in many European countries, some of which temporarily suspending vaccination with said pharmaceutical product.

Although research conducted at European level, mainly by the European Medicines Agency, has revealed the efficacy of the vaccine and the low degree of danger, the population refused vaccination with Astra Zeneca, moreover refusing to administer other vaccines, although the rate of side effects in their case was very low.

It is noted that the total number of side effects reported per thousand doses administered is 3,5/1000, being within the parameters accepted by the international medical community.

Specialists in the field claim that the small number of people who received the complete vaccination scheme has the effect of delaying the mass immunization of the population which would lead, implicitly, to the relaxation of restrictions and the return to a normal social life.

\section{Possible risk factors and threats to national security interests caused by the COVID-19 pandemic}

From a security perspective, referring to the special consequences generated medically [1], the pandemic caused by the SARS-CoV-2 coronavirus can generate in the medical field some risk factors that, if not properly managed, can turn the pandemic into a threat to national security, as stipulated in the National Defense Strategy for the period 2021-2024.

Risk factors generated by the COVID-19 pandemic include: 
$\square$ affecting the health level of the population with adverse consequences on life expectancy, knowing that specialized studies highlight certain side effects of coronavirus;

$\checkmark$ diminishing the response capacity of the medical system to other medical cases of citizens, in the context of adopting administrative measures that had the effect of reducing hospitalization capacity over various periods of time (especially in the first part of the pandemic), out of the need to prevent and limit the spread of the virus;

the impossibility of carrying out in good conditions national health programs and scientific research projects in the medical field, in the context of diminishing the level of allocation of budgetary resources, which were allocated with priority for the management of the COVID-19 pandemic;

the absence from work or the decrease of the work capacity for important periods of time of the persons infected with the new coronavirus, with negative consequences on the incomes of their families and of their contribution to the functioning of the national economy;

$\square$ severe restriction of most economic activities as a result of restrictions imposed for medical reasons, which has fundamentally affected the interests of national security in the economic field;

$\checkmark$ the alteration of the state of ,necessary balance and social stability”, as the alteration of the health status of the population affects the individual's capacity to contribute to the achievement of the objectives of the society as a whole;

The materialization of the risk factors previously presented may be likely to generate threats to the national security of Romania, in accordance with the provisions of Law no. 51/1991 regarding the national security of Romania [14], art.3, letter (f), being assimilated to actions likely to contribute to: „bringing into disuse the structures necessary for the proper conduct of social life" (Official Gazette of Romania, number 163/07 August 1991), well known being the role of the field of public health in the architecture of social security.

\section{Conclusions}

The end of 2019 and the beginning of the following year showed how unprepared the world of the 21 st century is for the management of global medical problems that can be exacerbated anytime and anywhere on a global scale.

The COVID-19 pandemic, an exceptional challenge for humanity, highlighted the role of international organizations in managing medical issues globally.

From a medical point of view, the pandemic is not yet resolved and will probably take a long time to achieve this goal, but it must be acknowledged that the science of the 21 st century has progressed enormously, so that in less than a year since the virus appeared, vaccines have been produced and tested to immunize the population, and from the end of 2020 they were launched on the market for widespread use.

As an EU member state, Romania has been actively involved in managing the complex issues caused by the COVID-19 pandemic, initiating coherent population testing and vaccination programs, even if public rhetoric has highlighted multiple deficiencies, at certain temporary moments, at least in terms of population testing.

Despite the institutional efforts made, Romania is currently among the last EU member states in terms of the percentage of vaccinated people, medical experts commenting on the serious consequences that may occur on the health of the population in the context of the manifestation of the fourth wave of the pandemic.

In addition to the role of institutions in managing the pandemic, the decisive role of citizens must not be overlooked in achieving success in the fight against this invisible and perverse enemy. Responsible behavior, civic attitude and support by citizens for institutional approaches (even if they have sometimes led to increased levels of fear of citizens, with detrimental influences on social behavior and mental health [2]), inclusive by accepting vaccination, in a public rhetoric laden with subjectivism and conspiracy theories are more than necessary. 
The concerted efforts of the medical world, national / international authorities and citizens will make humanity overcome the COVID-19 pandemic, but its consequences will be felt for a long time to come by humanity.

\section{References}

[1] Adid, Haleem; Mohd, Javaid, „Effects of COVID-19 pandemic in daily life”, in Current Medicine Research and Practice, No. 10(2), March-April, 2020, pp. 78-79, doi: 10.1016/j.cmrp.2020.03.011

[2] Brüssow, Harald; Timmis, Kenneth, „COVID - 19: long covid and its societal consequences”, in Environmental Microbiology, Nr. 23 (8), 2021, pp. 4086-4087, doi: 10.1111 / 14622920.15634.

[3] Conference „Dialogues at the Gate of Infinity. The third wave of the pandemic”, available at https://www.youtube.com/watch?v=khMmfXMY_Zk\&list=PLyaZRHc5R05emiXKpG7FY3 SJZ5tFB20_8\&index=74, accessed: 15.09.2021.

[4] Conference „COVID-19 virus and changing the world", available at https: //mail.google.com/mail/u/0/\#inbox/FMfcgzGljvPTchBTbNjfqLfqLLlSSklW? Projector $=1$, accessed: 16.09 .2021 .

[5] Corinavirus COVID-19 Romania, available at https://covid19.geo-spatial.org/statistici/statisticigenerale?chart=ziua-fata-de-cazuri-cumulative, accessed: 16.09.2021.

[6] Coronavirus COVID-19 Romania, available at https://covid19.geo-spatial.org/statistici/testeefectuate, accessed: 15.09.2021

[7] Coronavirus: Commission proposes rules (...) for Member States, available at https://ec.europa.eu/commission/presscorner/detail/en/ip_20_2483, accessed: 23.03.2021.

[8] COUNCIL RECOMMENDATION of 7 December 2018 on strengthening cooperation in the fight against vaccine-preventable diseases (2018 / C 466/01), available at https://eurlex.europa.eu/legal-content/RO/TXT/? uri = OJ\% 3AJOC_2018_466_R_0001, accessed: 20.03.2021.

[9] COVID_19 vaccines authorized in Romania, available at https://www.unicef.org/romania/media/5966/file/Vaccinuri\%20antiCovid\%20si\%20raportar e\%20reactii\%20adverse.pdf, accessed: 01.09.2021.

[10] Doctor Dodo Săndesc about COVID-19 (...) This disease can affect anyone, it's like Russian roulette, available at https://www.medichub.ro/stiri/medicul-dorel-sandesc-despre-covid-19aceasta -the-disease-can-affect-anyone-is-like-a-russian-roulette-id-3503-cmsid-2, accessed: 15.09.2021.

[11] How COVID-19 infection manifests itself: signs, symptoms and differences from the flu, available at https://www.reginamaria.ro/articole-medicale/cum-se-manifesta-infectia-covid19-semne-simptome-si -different-face-of-the-flu, accessed: 20.03.2021.

[12] Information Bulletin No. 10/2020. The main indicators of health knowledge for 2020 compared to 2019, available at https://cnsisp.insp.gov.ro/wp-content/uploads/2021/03/Buletininformativ-Principalii-indicatori-ai-cunoasterii- health-2020.pdf, accessed: 21.03.2021.

[13] Information Bulletin No. 11/2019. The main indicators of health knowledge for 2019 compared to 2018, available at https://cnsisp.insp.gov.ro/wp-content/uploads/2021/01/BuletinInformativ-Principalii-Indicatori-ai-Starii- de-Sanatate-2018_2019.pdf, accessed: 21.03.2021.

[14] Law no. 51/1991 on the national security of Romania, published in the Official Gazette of Romania, number 163/07 August 1991, accessed: 15.09.2021.

[15] Lurie, Nicole, et al. „Developing Covid-19 vaccines at pandemic speed”, în New England Journal of Medicine, 382.21 (2020): pp. 1969-1973.

[16] National Strategy for the Defense of the Country for the period 2021-2024, available at https://www.presidency.ro/files/userfiles/Strategia_Nationala_de_Aparare_a_Tarii_1.pdf, accessed: 18.03.2021.

[17] Peptan, Silvana, „Risks and threats to Romania's national security in the post-COVID-19 period”, 
Dissertation, master's degree in „Global Security Studies”, West University of Timișoara, 2021.

[18] Press releases, May 10, 2021, available at http://www.ms.ro/2021/05/10/testarea-rapida-infarmacii-pentru-depistarea-covid-19-aprobata-de-ministerul-sanatatii, accessed: 17.09.2021.

[19] Prevention of epidemics. Guide for companies and employees, MEDICI S ArztHaus.

[20] Reports, available at https://vaccinare-covid.gov.ro/raportari/, accessed: 16.09.2021.

[21] Romania, 2019 country profile in terms of health, available at https://ec.europa.eu/health/sites/health/files/state/docs/2019_chp_romania_romanian.pdf?fbc lid=IwAR3CQJ7UKkbJa9hz7R9iJ-8QjUXP9A, accessed: 19.03.2021.

[22] The Romanian Constitution,

available

at http://www.cdep.ro/pls/dic/site.page?den=act2_1\&par1=2, accessed: 16.03.2021.

[23] Vaccination: The European Commission and the World Health Organization join forces to promote the benefits of vaccines, available at https://ec.europa.eu/romania/news/20190912_vaccinare_comisia_europeana_organizatia__mon diala_sanatate_ro, accessed: 20.03.2021

[24] ***https: //www.graphs .ro / covid_ati.php? range = full, accessed: 15.09.2021.

[25] ***https://www.youtube.com/watch?v=x443K8-G7bg, accessed:16.09.2021.

[26] ***https://www.youtube.com/watch?v=E0nFNf4xJdc, accessed:16.09.2021. 